\title{
EVALUATING THE QUALITY OF SERVICES PROVIDED BY THE FINANCIAL CONTROLLER IN GOVERNMENTAL ORGANIZATIONS: USING THE SERVPERF MODEL
}

\author{
Ali A. Alnodel ${ }^{*}$, Naser Khlaifah ${ }^{* *}$, Hussein M. Elnafabi ${ }^{* *}$ \\ * Corresponding author, Accounting Department, College of Business and Economics, Qassim University, Buraydah, Saudi Arabia \\ Contact details: College of Business and Economics, Qassim University, P.O Box 4667 Buraydah, Alqassim, 51412, KSA, Saudi Arabia \\ ** Accounting Department, College of Business and Economics, Qassim University, Buraydah, Saudi Arabia
}

\begin{abstract}
OPEN ACCESS
How to cite this paper: Alnodel, A. A., Khlaifah, N., \& Elnafabi, H. M. (2020). Evaluating the quality of services provided by the financial controller in governmental organizations: Using the SERVPERF model. Journal of Governance \& Regulation, 9(2), 123-132.

http://doi.org/10.22495/jgrv9i2art10

Copyright (c) 2020 The Authors

This work is licensed under a Creative Commons Attribution 4.0 International License (CC BY 4.0).

https://creativecommons.org/licenses/by/ 4.0/

ISSN Print: 2220-9352

ISSN Online: $2306-6784$

Received: 06.05.2020

Accepted: 24.06 .2020

JEL Classification: M41, M42, M48 DOI: $10.22495 /$ jgrv9i2art 10
\end{abstract}

\begin{abstract}
Since governmental units are inefficient when it comes to public spending (Sutherland \& Price, 2007), this research aims to measure the quality of the level of services provided by the financial controller (FC) in Saudi governmental units. The SERVPERF model was employed to measure the quality of the level of services of FCs, in terms of what beneficiaries' desire and what already obtained. The study sample represents the beneficiaries of the services of FCs, specifically the accountants in the various government units. A t-test was used for paired samples in order to determine whether a fundamental difference exists between the level of service the recipient desires, according to the model dimensions, and what is actually being obtained. The results showed significant differences in the levels of assurance, sympathy, and tangibility, suggesting that recipients receive a lower level of services than what they desire. On the other side, the results showed no significant differences in the levels of reliability and responsiveness. These results reflect the nature of the traditional role of an FC, which is to ensure compliance with governmental regulations rather than the advisory role (Wilson, 2005). In light of the recent suggestions about financial control in government units (Rayp \& Van De Sijpe, 2007), this study recommends that the advisory role of FCs should be enhanced.
\end{abstract}

Keywords: Financial Controller, Financial Representative, Government Units, SERVPERF, Quality of Services, Public Expending

Authors' individual contribution: Conceptualization - A.A.A. and N.K.; Methodology - A.A.A. and N.K.; Data Curation - H.M.E. and A.A.A., Writing - Original Draft - A.A.A.; Writing - Review \& Editing - N.K. and H.M.E.; Formal Analysis - A.A.A. and H.M.E.; Investigation H.M.E.; Funding - Q.U.; Supervision - A.A.A.

Declaration of conflicting interests: The Authors declare that there is no conflict of interest.

Acknowledgements: The authors gratefully acknowledge Qassim University, represented by the Deanship of Scientific Research, on the material support for this research under the number (3447-cbe2018-1-14-S) during the academic year 1440 AH/2018 AD.

\section{INTRODUCTION}

In the Kingdom of Saudi Arabia, the Ministry of Finance is charged with the responsibilities of government expenditure and revenue raising in addition to developing economic policies and regulations and preparing the national budget (Ministry of Finance, 2019). According to the 
regulation of the Saudi Arabian public financial system, there are three parties that financially monitor government unites: the FC (representative of the Ministry of Finance), and the internal auditor, who is supposed to play the same role as the FC but follows the authority under which he works and monitors their accounts, and the public accountant or the external auditor appointed by companies and institutions that have a separated (independent) budget from the general national budget. In addition to the above-controlling bodies, the General Accounting Bureau is an independent body responsible for overseeing financial affairs and performances of all governmental units and reports to the Prime Minister. The system of financial representatives (FCs) imposed by Cabinet Resolution No. 471 of $06 / 03 / 1961$ states that for every government unit, an FC should be appointed to comply with financial instructions, making observations, and setting an annual program for the inspection of all units under their supervision and submitting their report to the Ministry of Finance (Ministry of Finance, 1961). The Ministry of Finance shall be the authority responsible for their appointment, transfer, dismissal, and issuance of instructions in the interest of the work. FCs examine the disbursement proposals and financial issues and their duties also include observing and explaining financial instructions on topics that need the approval of the Ministry of Finance and submit their reports to the Ministry of Finance once every 3 months. This system emphasizes FCs' independence and, at the same time, provides them with tools and authorities to help government units so they comply with public financial regulations and enhance efficiency and effectiveness of the financial performance of all government units. Thus, the research question can be phrased as follows: Does the financial controller (FC) in the Saudi Arabian public financial system provide his services with the desired level of quality?

Satisfaction is a diagnostic indicator that allows evaluating the expectations and measures consumer behavior (Iacobucci, Grayson, \& Ostrom, 1994; Paul, Mittal, \& Srivastav, 2016; Rezvani \& Safahani, 2016). Both customer expectations and perceptions about their levels of satisfaction are dynamic dimensions, this means that government administrations must measure them regularly to monitor them and check the gap being generated between them (Rodriguez, Campdesuner, Vidal, \& Vivar, 2017). In basic economic terms, goods and services represent the primary classifications of products. Both goods and services possess inherent characteristics that define their quality. In assessing and measuring quality, service quality is more difficult to evaluate than product quality since its final output is intangible, heterogeneous, and inseparable in nature (Parasuraman, Zeithaml, \& Berry, 1985). Between public and private service sectors, the evaluation of service quality can pose a major challenge to public service sectors given that they are generally under the administration of strict governments with clearly defined laws and regulations (Ocampo et al., 2019).

Government units suffer from the problems of the inefficiency of public spending, which leads to the financial waste of the nation's savings and major problems in achieving the goals of the state's operating budget (Saudi Vision 2030, 2018). These may be caused due to the state regulatory agencies inefficiently performing its role or not keeping pace with the needs of the beneficiaries of these services.
Very few studies have studied the performance of FCs in Saudi Arabian government agencies and applied the SERVPERF model in the work of financial observers in government units in general; to fill this gap, this study seeks to implement the SERVPERF model in examining whether FCs in government units provides their services with the required quality. According to the above, the research hypotheses are formulated according to the dimensions of the SERVPERF model (assurance, reliability, responsiveness, sympathy, and tangibility) in terms of what beneficiaries want in each dimension of this service and compare that to the level of service dimensions already present.

Due to the vast shift in the attitude of the Saudi Arabian government toward public expending at present, this study aims to contribute to these efforts in a number of ways. First, Saudi Vision 2030 emphasizes the strategic importance of rationalizing public expenditures by improving the level of transparency and accountability in order to improve the efficiency of government spending (Saudi Vision 2030, 2018). From this perspective, FCs in the government system are an important means of controlling these expenditures. Thus, this study could help by identifying deficiencies in the services of FCs in governmental units and then suggesting appropriate remedies. This study is also motivated by the importance of government expenditures in general. Previous studies have confirmed that oversight and follow-up have a major role in raising the efficiency of public expenditures, as the efficiency of government spending is a very important matter which is not related to the ability of governments, the size of the private sector in the state, or the directions and programs of governments but is rather essential for achieving stability in the economies of countries as a major advocate for continued economic growth (Gupta, Honjo, \& Verhoeven, 1997). Efficiency is influenced by several factors, the most important of which are organizational factors (Sutherland \& Price, 2007), and inefficiency in developing economies results mainly from administrative practices and behaviors and weak oversight (Wilson, 2005). Inefficiency in government expenditure is primarily determined by governance indicators and structural country variables (Rayp \& Van De Sijpe, 2007). The importance of this study can also be linked to educational and training programs, as the results of this study can help those responsible for these programs to develop their educational programs to qualify financial observers. This research is also one of the first studies that use this model in the accounting services in the Kingdom of Saudi Arabia, which could be a valuable contribution.

The rest of the paper is divided into six sections. The following section discusses previous studies investigating public spending and controls. Then, Section 3 discusses the research methodology and Sections 4 and 5 report the research results while Section 6 provides the conclusion.

\section{LITERATURE REVIEW}

Despite the importance of the role of the FC in raising the efficiency of public expenditures, a limited number of studies sought to evaluate the work of the FC in government institutions, especially in the Kingdom of Saudi Arabia. Most of these studies focus on the organizational aspects of the FC 
without sufficiently addressing the performance of the FC. Moreover, previous studies differed in their measurement of the efficiency of public expenditures from those that focused on concepts of efficiency and effectiveness, concerned with the methods used in measuring efficiency and indicators or focused on measuring the ability of organizations to achieve the desired goals of public expenditures. For example, Sutherland and Price (2007) reported that regulatory factors significantly affect public expenditures on education; Wilson (2005) emphasized that inefficiencies in developing economies result mainly from management practices and behaviors and weak oversight.

Customers can receive services from either the organizations of private sectors owned and controlled by private businesses or the administrations of public sectors that run and controlled by the government. Both private and public sectors can provide analogous services to their consumers but are distinctly different from one another (Ocampo et al., 2019). For example, while the organizations in private sectors generally make decisions in secrecy, the public sectors transparently share their plan to the public. Moreover, various considerations such as political and social responsibility are entailed to the public sector being a bargaining-based type of decisionmaker (Nutt, 2005). Accordingly, the public sector follows a bottom-up scheme in making decisions, while the private sector adopts a top-down decision process (Dillion, Buchanan, \& Corner, 2010). In a case that involves motivation of providing services, private sectors strive for a high level of profitability whereas public sectors desire to serve the public interest, loyalty to duty and the government collectively, and patriotism of benevolence (Ocampo et al., 2019).

Dang, Fargher, and Lee (2016) evaluated the quality of auditing for companies registered in the Chinese stock market and found that there is some evidence of high levels of personal appreciation when those companies are reviewed by small auditing firms. Johansen and Christoffersen (2016) evaluated the performance of the auditing firms and concluded that customers found no fundamental imbalance in-service performance. Waldmann and Ratnatunga (2015) examined the SERVPERF scale in the field of accounting services and concluded that this is one of the most successful measuring tools when it comes to the performance of accounting services.

Further, regarding the studies that concerned the quality of services and the methods for measuring them, there are many studies that dealt with evaluating the quality of services, and they were applied in several different sectors. For example, in determining the dimensions of quality of services, Zeitham, Parasuraman, and Berry (1985) presented quality dimensions represented in ten dimensions: reliability, response, efficiency, access to service, credibility, communication, safety, tact, tangibility, and understanding the customer. Adil and Ansari (2012) concluded that there is an effect of quality on the customer's conviction, lack of complaint, and loyalty in terms of providing service and increasing profitability. This study was preceded by several other studies that showed a relationship between the quality of service provided and the client's other behaviors (Buttle, 1996; Duncan \& Elliot, 2004; Lee \& Hwan, 2005; Lewis, 1991; Zeitham, Parasuraman, \& Berry, 1985). Several studies focused on the different dimensions of the service, whether tangible or intangible (Levesque \& McDougall, 1996; Wang, Lo, \& Hui, 2003). These studies mentioned that most of the technical aspects in the field of services have become normative by focusing on the impact of the customer and the service delivery team.

Previous studies agree that quality of service is abstract and difficult to define and measure accurately, because the characteristics are unique to each service compared to goods, such as the lack of physical presence, the method of production and consumption, as well as the inability to store them, and a person cannot know the nature of the service before receiving it. However, we find that most of these studies agree that the concept of quality of service is reflected through the evaluation of the customer, as he is the beneficiary of the service. This evaluation can be observed to a certain degree of excellence or total excellence in the performance of the service through the fulfillment of customer requirements or as the result of the difference between the final expectation of the beneficiary from the service and his awareness of the service performance he is already received (Al-Awlaki, 2018; Alabdadlah, 2017; Idris, 2012; Manik \& Sidharta, 2017).

In the literature, two models are frequently used to measure the quality of services: SERVOUAL and SERVPERF (Silva, de Moraes, Makiya, \& Cesar, 2017). The SERVQUAL scale is based on a form consisting of 22 items that reflect the five quality dimensions (tangibility, reliability, responsiveness, assurance, and sympathy). The scale consists of two groups, each of which contains 22 terms. The first group aims to determine the expected service, and the second group aims to perceive the actual service as follows: quality of service = performance expectations. The higher the perceived service the higher the customer's expectations (Salah Eldean \& Bartamani, 2018; Hamwi \& Ismail, 2011). Despite the widespread acceptance of the SERVQUAL scale, it was subjected to many criticisms, including the complexity of the mathematical operations involved, the weakening of its predictive capabilities, and its foundation on the model of contentment and not trends, in addition to the variance of its ability to explain the differences in the quality components from one industry to another (Al-Awlaki, 2018; Idris \& Al-Morsi, 1993).

These criticisms of the standards of SERVQUAL resulted in the continuous efforts made by researchers to arrive at a scientific and practical model for measuring the quality of service and enjoying a high degree of confidence, reliability, and applicability. The SERVPERF measure removes the gap between performance and expectations and focuses only on the actual performance of measuring the quality of service and, thus, exceeds ambiguity in building expectations. The advantages this scale has over the SERVQUAL scale are ease of application and measurement in addition to its degree of credibility and realism. Adil, Ghaswyneh, and Albkour (2013) concluded that the SERVPERF scale is one of the best measures to assess the quality of service performance. This was also confirmed by a study conducted by Vanpariya and Ganguly (2010).

Overall, our review of the literature reveals that despite the importance of the role of the FC in raising the efficiency of public expenditures, very few studies sought to evaluate the work of the FC in Saudi Arabian government units, where most studies 
mainly focused on the organizational aspects of the work of the FC without adequately addressing the performance of the FC. Further, the literature suggests that the SERVPERF scale is one of the best measures to assess the quality of service performance. Accordingly, this study uses the SERVPERF model to examine the equality of the services provided by FCs in the Saudi Arabian government units.

\section{RESEARCH METHODOLOGY}

The SERVPERF model is characterized by a high degree of credibility and appropriateness in assessing the performance of FCs. It was previously applied in a number of studies measuring the quality of services in various types of activities. These studies found that this is one of the most appropriate models, even more so than the SERVQUAL model to measure the quality of performance of accounting services (Waldmann \& Ratnatunga, 2011). The SERVPERF model includes multiple dimensions that reflect the quality of service dimensions. It measures the importance of each aspect of the expected services from the viewpoint of the beneficiaries of the service and compares that with the service already provided.

The SERVPERF model assumes that the quality of service provided falls into several dimensions, as follows: 1) assurance means providing the service to the recipient in a manner that is free from errors and risks, and this leads to reassurance by the recipient; 2) reliability expresses the ability of the FC to meet the needs of the recipient of the service, as represented by his commitment to the promises he made to the recipient of the service; 3) responsiveness reflects the response of the FC to the aspirations of the service recipient and the response to his requests and complaints and his initiative to provide the service; 4) sympathy expresses the FC's keenness on the recipient of the service and notifying him of its importance and his desire to build trust between them; 5) tangibility reflects aspects relating to physical appearances, including equipment and the appearance of the financial controller and his assistants. The study population represents the beneficiaries of the services of the financial controller, namely accountants in various government units. Accordingly, 48 questionnaires were distributed to a random sample from this community; 46 questionnaires were obtained, and 43 questionnaires have been used for this study after excluding 3 incomplete questionnaires. Data collection was conducted in May-July 2019.
This research might have also been conducted using the SERVQUAL model. It is a multidimensional research instrument composed of five dimensions: tangibility, reliability, responsiveness, empathy, and assurance. In the literature, the SERVQUAL model has been used to evaluate the quality of public services (Parasuraman, Zeithaml, \& Berry, 1988; Landrum, Prybutok, \& Zhang, 2010; Ocampo et al., 2019). Also, the use of SERVQUAL has been successfully implemented in various fields such as health services in government hospitals (AbuEid, Darawesh, \& Aydah, 2016), educational Services (Al-Awlki, 2018; Idris, 2012), public sector banks (Paul, Mittal, \& Srivastav, 2016), libraries and information services (Landrum, Prybutok, \& Zhang, 2010). Nevertheless, this model has been subject to a number of criticisms. Buttle (1996) reported a number of these criticisms such as problems with an operational definition of the expectations to construct, administration of the questionnaire, dimensional instability, operational definition of the expectations construct, the ambiguity of expectations construct, face validity and construct validity. One of the most important aspects that make using SERVPERF is preferable to using SERVQUAL is the administration aspect of the research instrument. SERVQUAL usually designed to be administered after beneficiaries have received the services that require them to recall their preexperience about the services. This could negatively affect the validity of the research instrument. Other research methods could also be used to answer the research questions such as surveys or interviews. Further research might adopt these alternative research methods.

\section{DESCRIPTIVE ANALYSIS}

With respect to the job ranking of the respondents as shown in Table 1 , the vast majority of respondents are from mid-tier positions and others from higher positions. Also, 72\% of respondents hold a bachelor's degree in accounting while those with a master's degree consisted of $2 \%$ of the sample. This means that respondents have the appropriate knowledge and qualification to respond to the questionnaires.

With respect to their professional qualification, it is clear from Table 1 that 23\% of the respondents have a CPA certificate and $77 \%$ do not have professional certificates. The average work experience of respondents is 15 years or more. Overall, respondents have the appropriate experience, qualifications, and positions to respond to the questionnaire.

Table 1. Respondents' demographic information

\begin{tabular}{|c|c|c|c|}
\hline Items & Group & No. & $\begin{array}{c}\text { Participants in the } \\
\text { sample (\%) }\end{array}$ \\
\hline \multirow{3}{*}{ Career rank } & 6th -8th hierarchy in government units* & 24 & 56 \\
\hline & 9th -12th hierarchy in government units & 23 & 53 \\
\hline & Non-bachelor holder & 11 & 26 \\
\hline \multirow{2}{*}{ Qualification } & Bachelor holder & 31 & 72 \\
\hline & Master holder & 1 & 2 \\
\hline \multirow{3}{*}{ Professional qualification } & Holding professional certificates & 10 & 23 \\
\hline & Not holding professional certifications & 33 & 77 \\
\hline & $0-4$ years & 11 & 26 \\
\hline \multirow{3}{*}{ Year of experience } & $5-9$ years & 9 & 21 \\
\hline & $10-15$ years & 2 & 4 \\
\hline & More than 15years & 21 & 49 \\
\hline
\end{tabular}

Note: * In Saudi government units, the highest career hierarchy is 15th. 


\section{DISCUSSION OF THE RESULTS}

This model depends on measuring the level of performance before and after getting the service. In other words, to measure the difference between observations recorded twice, we used a t-test. A t-test is frequently used to determine whether there is a fundamental difference between observations of a sample that may be related (paired samples) or unrelated (independent) samples. According to this model, the null hypothesis being tested states that there is no significant difference between the observations in the two measurements.

Since the purpose of the study is to measure the differences between the level of performance as desired by the beneficiary of the service and the level of performance that was actually obtained and since the observations recorded in the two phases are for the same sample, the t-test model for a paired (non-independent) sample is utilized to measure these differences. In this statistical model, the statistical value of $\mathrm{T}$ and the $\mathrm{t}$-distribution values and degrees of freedom are essential to determine the statistical significance of the results; for this statistical test, a number of conditions have been satisfied, and Cronbach's alpha is 87 .

\subsection{Assurance dimension}

The first hypothesis of the study concerns the assurance dimension of the SERVPERF model. To measure the difference between what the financial services recipient wants for the level of assurance and what he actually obtained, the first hypothesis was formulated as follows:

Hypothesis 1 (H1): There is no significant difference in the level of assurance that the beneficiary of the services of the financial controller in government units desires to obtain and the level of assurance that he actually received.

Table 2 shows the results of the paired sample t-test. It shows that the differences in the means between what the service recipient desires from FC at the assurance level (6.215) and what is actually obtained (5.889) are significant, where t $(42)=2.276$, $\mathrm{p}<.05, \mathrm{p} 2=.143$; indicating that there is an increase in what he wants (mean $=6.215)$, standard deviation $=0.753$, sample size $=43)$, compared to what it actually received (mean $=5.888$, standard deviation $=0.959$, sample size $=43$ ) .

Table 2. Paired sample t-test for the assurance level

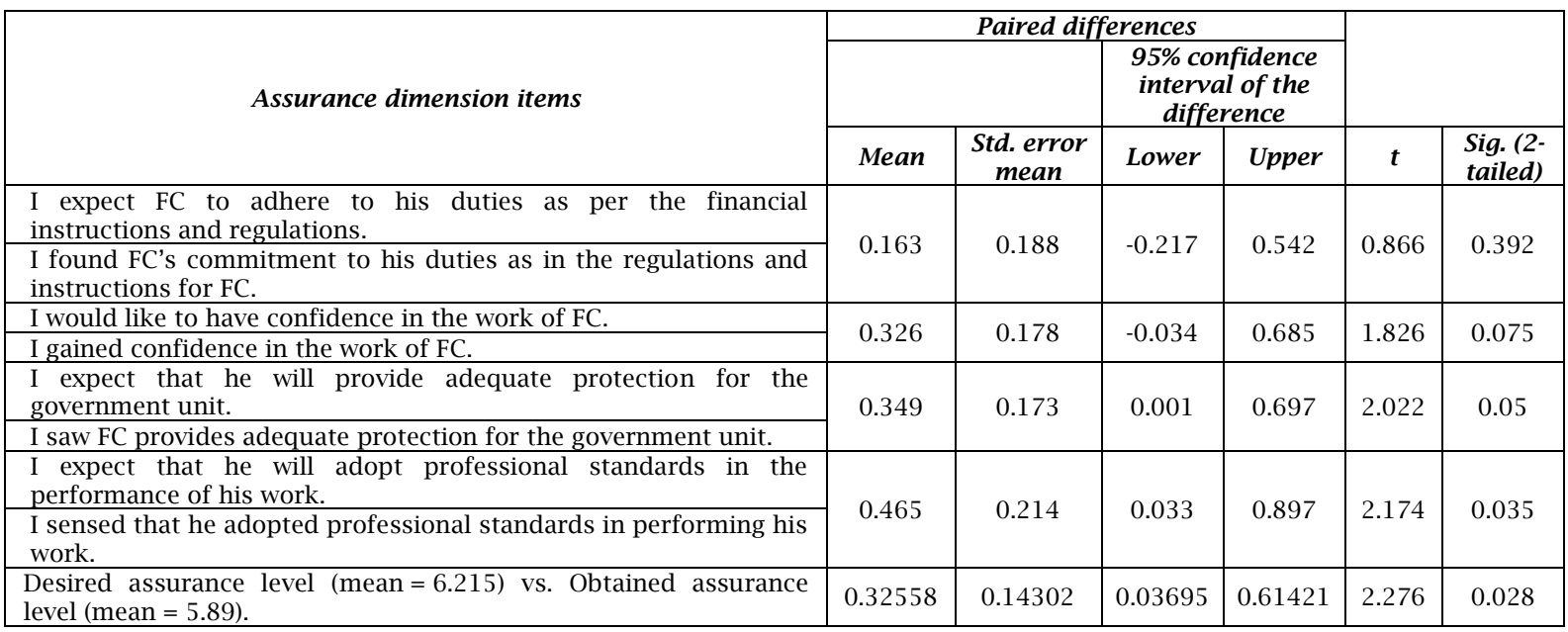

The difference is fundamental as the average increase was 0.326 with a 95\% confidence level for the difference between 0.614 and 0.037 averages. Therefore, we rejected the null hypothesis, which states that there is no significant difference in the level of assurance that the service recipient desires and what he obtains from the FC in the government units. These results are supported by testing the detailed items of the assurance dimension. Most of the items of this dimension indicate that there are differences between what the service recipient desires from the level of assurance and what he actually received.

\subsection{Reliability dimension}

The second hypothesis examines the reliability dimensions. To measure the difference between what the financial services recipient desires for the level of reliability and what he actually obtained, the second hypothesis was formulated as follows:

Hypothesis 2 (H2): There is no significant difference in the level of reliability that the beneficiary of the services of the financial controller in government units desires to obtain and the level of reliability that he actually received.

Table 3 shows the results of the paired sample t-test. The results show that the differences in the means between what the service recipient desires for the level of reliability (5.93) and what he actually received (5.74) are insignificant, where $t(42)=1.293$, $\mathrm{p}>.05, \mathrm{n} 2=.144$, indicating that there are no differences in the level of performance between what the financial services recipient desire in terms of reliability and what he actually receives. It shows no change in what the service recipient desires (mean $=5.93$, standard deviation $=0.789$, sample size $=43$ ) compared to what he actually received $($ mean $=5.744$, standard deviation $=0.777$, sample size $=43$ ). 
Table 3. Paired sample t-test for reliability dimension

\begin{tabular}{|c|c|c|c|c|c|c|}
\hline \multirow{3}{*}{ Reliability dimension items } & \multicolumn{4}{|c|}{ Paired differences } & \multirow[b]{3}{*}{$t$} & \multirow[b]{3}{*}{$\begin{array}{l}\text { Sig. }(2- \\
\text { tailed) }\end{array}$} \\
\hline & \multirow[b]{2}{*}{ Mean } & \multirow[b]{2}{*}{\begin{tabular}{|c|}
$\begin{array}{c}\text { Std. error } \\
\text { mean }\end{array}$ \\
\end{tabular}} & \multicolumn{2}{|c|}{$\begin{array}{l}\text { 95\% confidence } \\
\text { interval of the } \\
\text { difference }\end{array}$} & & \\
\hline & & & Lower & Upper & & \\
\hline $\begin{array}{l}\text { I would like to rely on FC to address the problems of the } \\
\text { government unit in which he is present. }\end{array}$ & \multirow{2}{*}{0.000} & \multirow{2}{*}{0.191} & \multirow{2}{*}{-0.386} & \multirow{2}{*}{0.386} & \multirow{2}{*}{0.000} & \multirow{2}{*}{1.000} \\
\hline $\begin{array}{l}\text { I got the ability to rely on him to tackle the problems of the } \\
\text { government unit, he is in. }\end{array}$ & & & & & & \\
\hline I expect that FC will get the job is done right the first time. & \multirow{2}{*}{-0.163} & \multirow{2}{*}{0.208} & \multirow{2}{*}{-0.582} & \multirow{2}{*}{0.256} & \multirow{2}{*}{-0.784} & \multirow{2}{*}{0.437} \\
\hline I felt the job was done correctly the first time. & & & & & & \\
\hline I hope that FC will complete the task at the agreed time. & \multirow{2}{*}{0.429} & \multirow{2}{*}{0.208} & \multirow{2}{*}{0.009} & \multirow{2}{*}{0.848} & \multirow[b]{2}{*}{2.063} & \multirow{2}{*}{0.045} \\
\hline I saw the task completed in the agreed time. & & & & & & \\
\hline $\begin{array}{l}\text { I would like to have confidence that the work assigned to FC will } \\
\text { end in its time. }\end{array}$ & \multirow{2}{*}{0.465} & \multirow{2}{*}{0.224} & \multirow{2}{*}{0.013} & \multirow{2}{*}{0.917} & \multirow{2}{*}{2.075} & \multirow{2}{*}{0.044} \\
\hline $\begin{array}{l}\text { I got the confidence that the work assigned to him will be } \\
\text { completed in his time. }\end{array}$ & & & & & & \\
\hline $\begin{array}{l}\text { I expect that FC will have sufficient experience to help him } \\
\text { follow up the needs of the government unit. }\end{array}$ & \multirow{2}{*}{0.326} & \multirow{2}{*}{0.220} & \multirow{2}{*}{-0.118} & \multirow{2}{*}{0.770} & \multirow{2}{*}{1.480} & \multirow{2}{*}{0.146} \\
\hline $\begin{array}{l}\text { I found FC has sufficient experience to assist in following up the } \\
\text { needs of the government unit. }\end{array}$ & & & & & & \\
\hline $\begin{array}{l}\text { Desired reliability level }(\text { mean }=5.93) \text { vs. Obtained reliability } \\
\text { level }(\text { mean }=5.74) \text {. }\end{array}$ & 0.186 & 0.144 & -0.104 & 0.476 & 1.293 & 0.203 \\
\hline
\end{tabular}

The difference is not significant since the average increase was 0.186 with $95 \%$ confidence for the difference between the average of 0.476 and the average of 0.104 . Therefore, we accepted the null hypothesis, which stipulates that there is no significant difference in the level of reliability that the beneficiary of the services of the FC in government units desires to obtain and the level of reliability that he actually received. These results are supported by testing the detailed items of the reliability dimension, as most items of this dimension indicate that there are no differences between what the service recipient desires from the level of reliability and what he actually received.

\subsection{Responsiveness dimension}

Responsiveness refers to the FC's reaction to the aspirations of the service recipient, his requests and complaints, and to the financial controller's initiative to provide the service to them. To measure the difference between what the financial services recipient in the government units would like for the responsiveness level and what was actually obtained, the third hypothesis is stated as follows:

Hypothesis 3 (H3): There is no significant difference in the level of responsiveness that the beneficiary of the services of the financial controller in government units desires to obtain and the level of responsiveness that he actually received.

Table 4 shows that there is no significant difference in the means between what the service recipient desires for the level of responsiveness (6.03) and what he actually obtained (5.78). As it turns out, $\mathrm{t}(42)=1.528, \mathrm{p}>.05, \mathrm{p} 2=.164$, indicating that there is no difference in the level of performance in terms of the responsiveness aspect between what the receiver of the FC desires (mean $=6.03$, standard deviation $=0.903$, sample size $=43)$ and what he actually received (mean $=5.779$, standard deviation $=0.934$, sample size $=43)$.

Table 4. Paired sample t-test for the responsiveness dimension

\begin{tabular}{|c|c|c|c|c|c|c|}
\hline \multirow{3}{*}{ Responsiveness dimension items } & \multicolumn{4}{|c|}{ Paired differences } & \multirow[b]{3}{*}{$t$} & \multirow[b]{3}{*}{$\begin{array}{l}\text { Sig. (2- } \\
\text { tailed) }\end{array}$} \\
\hline & \multirow[b]{2}{*}{ Mean } & \multirow{2}{*}{$\begin{array}{c}\text { Std. error } \\
\text { mean }\end{array}$} & \multicolumn{2}{|c|}{$\begin{array}{c}\text { 95\% confidence } \\
\text { interval of the } \\
\text { difference }\end{array}$} & & \\
\hline & & & Lower & Upper & & \\
\hline $\begin{array}{l}\text { I hope the FC will respond to the requirements of the } \\
\text { government unit. }\end{array}$ & \multirow[t]{2}{*}{0.023} & \multirow[t]{2}{*}{0.206} & \multirow[t]{2}{*}{-0.393} & \multirow[t]{2}{*}{0.440} & \multirow[t]{2}{*}{0.113} & \multirow[t]{2}{*}{0.911} \\
\hline I saw FC's response to the requirements of the government unit. & & & & & & \\
\hline I hope FC understands the needs of the government unit. & \multirow{2}{*}{0.372} & \multirow{2}{*}{0.191} & \multirow{2}{*}{-0.014} & \multirow{2}{*}{0.758} & \multirow{2}{*}{1.946} & \multirow{2}{*}{0.058} \\
\hline I felt FC's understanding of the needs of the government unit. & & & & & & \\
\hline I hope FC deals with the government unit effectively. & \multirow{2}{*}{0.395} & \multirow{2}{*}{0.216} & \multirow{2}{*}{-0.041} & \multirow{2}{*}{0.831} & \multirow{2}{*}{1.830} & \multirow{2}{*}{0.074} \\
\hline I found that he deals with the governmental unit effectively. & & & & & & \\
\hline $\begin{array}{l}\text { I expect FC to respond to the needs and interests of the } \\
\text { government unit. }\end{array}$ & \multirow{2}{*}{0.209} & \multirow{2}{*}{0.204} & \multirow{2}{*}{-0.202} & \multirow{2}{*}{0.621} & \multirow{2}{*}{1.026} & \multirow{2}{*}{0.311} \\
\hline $\begin{array}{l}\text { I touched his response to the needs and interests of the } \\
\text { government unit }\end{array}$ & & & & & & \\
\hline $\begin{array}{l}\text { Desired responsiveness level }(\text { mean }=6.033) \\
\text { responsiveness level }(\text { mean }=5.778)\end{array}$ & 0.250 & 0.164 & -0.080 & 0.580 & 1.528 & 0.134 \\
\hline
\end{tabular}

The difference is not material as the average increase is 0.250 with a $95 \%$ confidence level for the difference between the average of 0.580 and the average of 0.080 . Thus, we rejected the null hypothesis, which stipulates that there is no significant difference in the level of responsiveness that the beneficiary of the FC's services in government units desire to obtain and the level of 
responsiveness that he actually received. These results are supported by testing the detailed items of the responsiveness dimension. Most of the items of this dimension indicate that there are no differences between what the service recipient desires from the level of responsiveness and what he gets.

\subsection{Sympathy dimension}

Sympathy dimension refers to the keenness of the FC toward the recipient of the service by showing the importance and desire to build trust between them. To measure the difference between what the financial services recipient in government units desires for the level of sympathy and what he actually obtained, the fourth hypothesis is formulated as follows:

Hypothesis 4 (H4): There is no significant difference in the level of sympathy that the beneficiary of the services of the financial controller in government units desires to obtain and the level of sympathy that he actually received.

Table 5 shows the results of the paired sample t-test for the differences in the means between what the service recipient desires from the level of sympathy (6.13) and what he actually obtained (5.69), where the results show that there is a significant difference $\mathrm{t} \quad(42=3.099, \mathrm{p}<.05$, $\mathrm{y} 2=.140$ ), indicating that there are differences in the level of performance between what the financial services recipient desire in terms of sympathy and what he actually obtained.

Table 5. Paired sample t-test for the sympathy dimension

\begin{tabular}{|c|c|c|c|c|c|c|}
\hline \multirow{3}{*}{ Sympathy dimension items } & \multicolumn{4}{|c|}{ Paired differences } & \multirow[b]{3}{*}{$t$} & \multirow[b]{3}{*}{$\begin{array}{l}\text { Sig. (2- } \\
\text { tailed) }\end{array}$} \\
\hline & \multirow[b]{2}{*}{ Mean } & \multirow[b]{2}{*}{$\begin{array}{c}\text { Std. error } \\
\text { mean }\end{array}$} & \multicolumn{2}{|c|}{$\begin{array}{c}95 \% \text { confidence } \\
\text { interval of the } \\
\text { difference }\end{array}$} & & \\
\hline & & & Lower & Upper & & \\
\hline $\begin{array}{l}\text { I expect that FC will have the desire to serve the government } \\
\text { unit. }\end{array}$ & \multirow[t]{2}{*}{0.372} & \multirow[t]{2}{*}{0.173} & \multirow[t]{2}{*}{0.023} & \multirow[t]{2}{*}{0.721} & \multirow[t]{2}{*}{2.151} & \multirow[t]{2}{*}{0.037} \\
\hline I sensed that the FC's desire to serve the government unit. & & & & & & \\
\hline $\begin{array}{l}\text { I expect that FC will have personal care and concern for } \\
\text { government unity. }\end{array}$ & \multirow{2}{*}{0.326} & \multirow{2}{*}{0.175} & \multirow{2}{*}{-0.028} & \multirow{2}{*}{0.679} & \multirow{2}{*}{1.858} & \multirow{2}{*}{0.07} \\
\hline $\begin{array}{l}\text { I felt the concern and personal attention of the FC for the } \\
\text { government unit. }\end{array}$ & & & & & & \\
\hline $\begin{array}{l}\text { I hope the FC will respond quickly to the needs of the } \\
\text { government unit. }\end{array}$ & \multirow[t]{2}{*}{0.465} & \multirow[t]{2}{*}{0.217} & \multirow[t]{2}{*}{0.028} & \multirow[t]{2}{*}{0.902} & \multirow{2}{*}{2.148} & \multirow[t]{2}{*}{0.038} \\
\hline I found a rapid response to the needs of the government unit by FC. & & & & & & \\
\hline $\begin{array}{l}\text { I want him to embrace the defense of the needs of the } \\
\text { government unit. }\end{array}$ & \multirow{2}{*}{0.465} & \multirow{2}{*}{0.209} & \multirow{2}{*}{0.044} & \multirow{2}{*}{0.886} & \multirow{2}{*}{2.228} & \multirow{2}{*}{0.031} \\
\hline $\begin{array}{l}\text { I found that he adopted the defense of the needs of the } \\
\text { government unit. }\end{array}$ & & & & & & \\
\hline I expect FC's presence and easy communication with him. & \multirow{2}{*}{0.535} & \multirow{2}{*}{0.201} & \multirow{2}{*}{0.13} & \multirow{2}{*}{0.94} & \multirow{2}{*}{2.666} & \multirow{2}{*}{0.011} \\
\hline I found his presence and the ease of communicating with him. & & & & & & \\
\hline $\begin{array}{l}\text { Desired sympathy level }(\text { mean }=6.128) \text { vs. Obtained sympathy } \\
\text { level }(\text { mean }=5.692) \text {. }\end{array}$ & 0.43256 & 0.1396 & 0.15084 & 0.7143 & 3.099 & 0.003 \\
\hline
\end{tabular}

The results show an increase in what he desires (mean $=6.13$, standard deviation $=0.657$, sample size $=43$ ) compared to what he actually observed (mean $=5.693$, standard deviation $=0.886$, sample size $=43$ ). This difference is substantial, and the average increase is 0.433 with a confidence level of $95 \%$ for the difference between the average of 0.714 and an average of 0.15 . Therefore, the null hypothesis stipulating that there is no significant difference in the level of sympathy desired by the financial services recipient from the FC in government units, and the level of sympathy that is actually obtained is rejected. These results are supported by testing the detailed items of the sympathy dimension. Most of the items of this dimension indicate that there are differences between what the service recipient desires from the level of sympathy and what actually received.

\subsection{Physical appearance dimension}

The physical or tangible dimension expresses the physical manifestations, including the equipment and the appearance of the financial controller and his assistants. To measure the difference between what the financial services recipient in government units desires from the FC for the physical level and what he actually obtained, the fifth hypothesis was formulated as follows:

Hypothesis 5 (H5): There is no significant difference in the level of physical appearance that the beneficiary of the services of the financial controller in government units desires to obtain and the level of physical appearance that he actually received.

Table 6 shows the results of the t-test for a paired sample. It demonstrates that the results are found to be significant where $t(42)=3.276, p<.05$, $\mathrm{n} 2=.166$, indicating that there are differences in the level of performance between what the recipient of the services of the FC desires in terms of physical appearance and what he actually gets. 
Table 6. Paired sample t-test for the physical appearance dimension

\begin{tabular}{|c|c|c|c|c|c|c|}
\hline \multirow{3}{*}{ Physical appearance dimension items } & \multicolumn{4}{|c|}{ Paired differences } & \multirow[b]{3}{*}{$t$} & \multirow[b]{3}{*}{$\begin{array}{l}\text { Sig. (2- } \\
\text { tailed) }\end{array}$} \\
\hline & \multirow[b]{2}{*}{ Mean } & \multirow[b]{2}{*}{$\begin{array}{l}\text { Std. error } \\
\text { mean }\end{array}$} & \multicolumn{2}{|c|}{$\begin{array}{l}\text { 95\% confidence } \\
\text { interval of the } \\
\text { difference }\end{array}$} & & \\
\hline & & & Lower & Upper & & \\
\hline I expect that he will use modern technology to perform his duties. & \multirow{2}{*}{0.698} & \multirow{2}{*}{0.261} & \multirow{2}{*}{0.171} & \multirow{2}{*}{1.224} & \multirow{2}{*}{2.673} & \multirow{2}{*}{0.011} \\
\hline I saw that he uses modern technology. & & & & & & \\
\hline $\begin{array}{l}\text { I would like the work of the FC to be orderly and in good } \\
\text { appearance. }\end{array}$ & \multirow{2}{*}{0.512} & \multirow{2}{*}{0.177} & \multirow{2}{*}{0.154} & \multirow{2}{*}{0.869} & \multirow{2}{*}{2.886} & \multirow{2}{*}{0.006} \\
\hline $\begin{array}{l}\text { I found that the work of the FC is organized and in good } \\
\text { appearance. }\end{array}$ & & & & & & \\
\hline $\begin{array}{l}\text { I hope that he will use the appropriate means of communication to } \\
\text { work clearly. }\end{array}$ & \multirow{2}{*}{0.419} & \multirow{2}{*}{0.189} & \multirow{2}{*}{0.037} & \multirow{2}{*}{0.8} & \multirow{2}{*}{2.216} & \multirow{2}{*}{0.032} \\
\hline $\begin{array}{l}\text { I saw that he was using the appropriate means of communication } \\
\text { to work clearly. }\end{array}$ & & & & & & \\
\hline $\begin{array}{l}\text { Desired physical appearance level }(\text { mean }=6.267) \text { vs. Obtained } \\
\text { physical appearance level }(\text { mean }=5.713) .\end{array}$ & 0.5426 & 0.1657 & 0.208 & 0.877 & 3.276 & 0.002 \\
\hline
\end{tabular}

As in Table 6, there is an increase in what he desires $($ mean $=6.256$, standard deviation $=0.854$, sample size $=43$ ) compared to what he actually obtained (mean $=5.713$, standard deviation $=1.118$ sample size $=43$ ). The average increase is 0.543 with a confidence level of $95 \%$ for the difference between the average of 0.877 and the average of 0.208 , suggesting that the beneficiary of the services of the FC in government units desires more than what he receives with respect to the level of physical appearances. Therefore, we rejected the fifth null hypothesis suggesting that there is no significant difference in the level of physical appearance that the beneficiary of the services of the FC in government units desires to obtain and what he actually observes. These results are supported by testing the detailed items of the physical appearance dimension, as most items of this dimension indicate that there are differences between what has been desired by the service recipient and what is actually obtained.

\section{CONCLUSION}

This study aims to apply the SERVPERF model in answering the main question: Does the financial controller in government units provide his services with the desired quality? This study applied the SERVPERF model to a sample of the beneficiaries of the services of the FC in government units. The study population is the accountants in government units in the Kingdom of Saudi Arabia. The questionnaires were distributed to a random sample of this community, and the response rate was 90\%. Forty-three questionnaires were usable.

A paired sample t-test was used to determine whether there are statistically significant differences between the means of what the receiver of the financial services in government units desires in terms of the five dimensions of the SERVPERF model and what is actually obtained according to these dimensions. The results of the study indicate the existence of significant differences in three of these dimensions: assurance, sympathy, and physical appearance; the desires of the recipient of the financial service exceed what was obtained. On the other hand, the results do not show significant differences between what the service recipient desires and what has already been achieved on the levels of reliability and responsiveness, as the averages are very close. The nature of the work of the FC in government units can explain these results. The FC, as a supervisory body appointed by the
Ministry of Finance, operates according to specific financial regulations and rules. It is expected that his work will concentrate on the reliability and responsiveness of the government units according to the regulated policies and regulations. Therefore, these results reflect the traditional nature of the work of the FC. From the reliability aspect, he should seek to reconcile the work of government units with financial regulations and rules. This is the essence of FC's work. In terms of responsiveness, he seeks to ease the financial work of government units by observing financial regulations and responding to the needs of government units. The desires of the receiver of the financial services of the $\mathrm{FC}$ in government units might be beyond the scope of these traditional aspects of the work of the FC. Although this might be reasonable, considering other dimensions of the work of the FC in government units may enhance the control environment in government organizations.

Accordingly, this study recommends increasing focus on other aspects of the qualification of the financial controller, which represents the recent trends in the work of FCs. The FC or financial auditor works in a system. Promoting the success of this system raises the levels of sympathy and assurance between those associated with this system from regulatory agencies and auditees subject to the quality control system. Also, educational programs to qualify FCs can enhance their position by increasing their qualification in the use of technology and other material means. With the scarcity of studies dealing with the role of the FC in government units, this study also encourages studies dealing with the role of the FC in government agencies, especially with the directions of Saudi Vision 2030 to rationalize government spending.

Like other studies, this study has some limitations that should be taken into account when evaluating the results. In terms of the sample, despite the care being taken in distributing and collecting questionnaires, the absence of specific lists for the population of the study must be taken into account, for example, not covering all recipient categories of the services of the FC. Also, the SERVPERF model used in this study has been modified in proportion to the function of the FCs in Saudi Arabian government units. Previous studies that used the SERVPERF model have also made similar modifications to match the reality of the situation. Nevertheless, the results of this study should be read within this modification. 


\section{REFERENCES}

1. AbuEid, R. A., Darawesh, A., \& Aydah, F. (2016). Evaluation of the quality of health services in government hospitals operating in the southern west bank using the (SERVPERF) scale. Journal of Studies, Administrative Sciences, 34(2). Retrieved from https://platform.almanhal.com/Files/2/96854

2. Adil, M., \& Ansari, S. A. (2012). Service quality and customer loyalty at Indian rural banks: An empirical test of an integrative model. Proceedings of the National Conference on Contemporary Issues in Business, Management \& Finance.

3. Adil, M., Al Ghaswyneh, O. F. M., \& Albkour, A. M. (2013). SERVQUAL and SERVPERF: A review of measures in services marketing research. Global Journal of Management and Business Research Marketing, 13(6), 65-76. Retrieved from https://globaljournals.org/GJMBR_Volume13/5-SERVQUAL-and-SERVPERF.pdf

4. Ahmed, S., \& Harara, A. (2016). The effect of efficiency and effective financial control on rationalization of expenditure: Case study (Aqaba Special Economic Zone Authority). Retrieved from https://meu.edu.jo/libraryTheses/59045cb156020_1.pdf

5. Alabadlah, T. O. (2017). Study of factors affecting measurement of perceived quality of educational services using the gap analysis model-SERVQUAL. IUG. Journal of Economics and Business, 25(3), 1-13. https://doi.org/10.12816/0041513

6. Al-Awlaki, A. A. (2018). Impact of using SERVPERF scale to measure the quality of educational services on students' satisfaction at Ibb University - Yemen. The Arab Journal for Quality Assurance in University Education, 11(37), 125-146. https://doi.org/10.20428/AJQAHE.11.37.6

7. Al-Sabaie, S. A. (2014). Measuring the quality of Islamic banking services from the clients' perspective: An applied study on some Saudi Islamic banks. https://doi.org/10.33095/jeas.v23i97.305

8. Bentley-Goode, K. A., Newton, N. J., \& Thompson, A. (2017). Business strategy and internal control over financial reporting. https://doi.org/10.2139/ssrn.2637688

9. Biondi, Y. (2013). Governmental accounting and austerity policies: Accounting representations of public debt and deficit in Europe and abroad. Accounting, Economics and Law Research Network Conference, SASE Annual Meeting, University of Milano, June 27-29, 2013. Retrieved from http://www.maxpo.eu/downloads/yuri_biondi.pdf

10. Biondi, Y. (2016). The HM treasure's island: The Application of Accruals-based Accounting Standards in the UK Government. Accounting in Europe, 13(1), 1-22. https://doi.org/10.1080/17449480.2016.1142096

11. Buttle, F. (1996). SERVQUAL: Review, critique, research agenda. European Journal of Marketing, 30(1), 8-32. https://doi.org/10.1108/03090569610105762

12. Cardoso, R. L., Aquino, A. C. B., \& Pigatto, J. (2014). Brazilian governmental accounting reforms: IPSAS and accrual accounting adoption. https://doi.org/10.2139/ssrn.2466484

13. Choudhary, P., Merkley, K., \& Schipper, K. (2019). Auditors' quantitative materiality judgments: Properties and implications for financial reporting reliability. Journal of Accounting Research, 57(5), 1303-1351. https://doi.org/10.1111/1475-679X.12286

14. Cronin, J. J., \& Taylor, S. A. (1992). Measuring services quality: Reexamination and extension. Journal of Marketing, 56(3), 55-68. https://doi.org/10.2307/1252296

15. Dang, C. M., Fargher, N., \& Lee, G. (2016). Audit quality for US-listed Chinese companies. International Journal of Auditing, 21(2), 150-163. https://doi.org/10.1111/ijau.12085

16. Darwish, M. J. (2009). The effect of the quality of services provided by municipalities in Palestine on the satisfaction of beneficiaries. Paper presented at International Administrative Development Conference. Institute of Public Administration, Saudi Arabia, November 1-4, $2009 . \quad$ Retrieved from https://slideum.com/doc/5149705/

17. Dillion, S., Buchanan, J., \& Corner, J. (2010). Comparing public and private sector decision-making: Problem structuring and information quality issues. Proceedings of the 45th Annual Conference of the ORSNZ. Retrieve from http://citeseerx.ist.psu.edu/viewdoc/download?doi=10.1.1.455.9291\&rep=rep1\&type=pdf

18. Duncan, E., \& Elliott, G. (2004). Efficiency, customer service and financial performance among Australian financial institutions. International Journal of Bank Marketing, 22(5), 319-342. https://doi.org/10.1108/02652320410549647

19. Feroz, E. H. (1986). Group participation in governmental accounting standards setting: A cluster analysis. Public Administration Quarterly, 9(4), 470-485. https://doi.org/10.2139/ssrn.1306684

20. Gupta, S., Honjo, K., \& Verhoeven, M. (1997). The efficiency of government expenditure: Experience from Africa (IMF Working Paper No. 97/153). Retrieved from https://www.imf.org/external/pubs/ft/wp/wp97153.pdf

21. Hamwi, F., \& Ismail, M. (2011). Measuring service quality in the Syrian banking sector: A comparative field study between private and public banks. Tishreen University Journal for Research and Scientific Studies - Economic and Legal Sciences Series, 33(6), 105-124.

22. Iacobucci, D., Grayson, K. A., \& Ostrom, A. L. (1994). The Calculus of service quality and customer satisfaction theoretical and empirical differentiation and integration. In T. A. Swartz, D. E. Bowen, \& S. W. Brown (Eds.), Advances in services marketing and management research and practice (pp. 1-67). Greenwich, CT: JAI Press Inc.

23. Idris, T. A. (2012). Obstacles to quality and accreditation management in Egyptian governmental universities according to the perceptions of academic leadership: An exploratory study. New Horizons Journal, 24(1), 10-89.

24. Idris, T. A., \& Al-Morsi, J. A. (1993). Measuring service quality and analyzing the relationship between it and each feeling of satisfaction and tendency to buy: An applied systematic entrance. Scientific Journal of Trade and Finance, 13(1), 147-196.

25. INTOSAI (2014). The International Journal of Governmental Control. Retrieved from INTOSAI website: http://intosaijournal.org/

26. Jain, A., \& Roy, B. K. (2018). Tradeoff between quality of control (OoC) and quality of service (OoS) for networked vehicles cruise control. Proceedings of the 3rd International Conference on Internet of Things and Connected Technologies. https://doi.org/10.2139/ssrn.3167436

27. Johansen, T. R., \& Christoffersen, J. (2016). Performance evaluations in audit firms: Evaluation foci and dysfunctional behaviour. International Journal of Auditing, 21(1), 24-37. https://doi.org/10.1111/ijau.12079

28. Kaya, D., Kirsch, R. J., \& Henselmann, K. (2017). The role of non-governmental organizations (NGOs) as intermediaries of the European Union decision to adopt International Accounting Standards: 1973-2002. Accounting Historians Journal, 43(2), 59-127. https://doi.org/10.2308/0148-4184.43.2.59 
29. Khalifa, N., \& Alnodel, A. (2015). Measuring the quality of services of auditing firms in the Kingdom of Saudi Arabia using the scale of expectations and perceptions. Journal of Saleh Kamel Center for Islamic Economics.

30. Landrum, H., Prybutok, V. R., \& Zhang, X. (2010). The moderating effect of occupation on the perception of information services quality and success. Computers \& Industrial Engineering, 58(1), 133-142. https://doi.org/10.1016/j.cie.2009.09.006

31. Lee, M. C., \& Hwan, I. S. (2005). Relationships among service quality, customer satisfaction and profitability in the Taiwanese banking industry. International Journal of Management, 22, 635-648.

32. Levesque, T., \& McDougall, G. H. G. (1996). Determinants of customer satisfaction in retail banking. International Journal of Bank Marketing, 14(7), 12-20. https://doi.org/10.1108/02652329610151340

33. Lewis, B. R. (1991). Service quality: An international comparison of bank customers' expectations and perceptions. Journal of Marketing Management, 7(1), 47-62. https://doi.org/10.1080/0267257X.1991.9964139

34. Manik, E., \& Iwan, S. (2017). The impact of academic service quality on students satisfaction (MPRA Paper No.80878). Retrieved from https://mpra.ub.uni-muenchen.de/80878/1/MPRA_paper_80878.pdf

35. Ministry of Finance. (1961). Financial representatives system. Retrieved from https://www.mof.gov.sa/Pages/default.aspx

36. Ministry of Finance. (2019). Terms of reference of ministry of finance. Retrieved from https://www.mof.gov.sa/en/about/Pages/-specialization.aspx

37. Nutt, P. C. (2005). Comparing public and private sector decision-making practices. Journal of Public Administration Research and Theory, 16(2), 289-318. https://doi.org/10.1093/jopart/mui041

38. Ocampo, L., Alinsub, J., Casul, R. A., Enquig, G., Luar, M., Panuncillon, N., Bongo, M., \& Ocampo, C. O. (2019). Public service quality evaluation with SERVQUAL and AHP-TOPSIS: A case of Philippine government agencies. Socio-Economic Planning Science, 68. https://doi.org/10.1016/j.seps.2017.12.002

39. Othman, O., \& Albana, B. (2012). Evaluating the impact of financial control by the audit bureau on public institutions in Jordan. Egyptian Journal of Business Studies. Retrieved from https://www.iu.edu.jo/files/managemnt/publication/\%D9\%82\%D8\%B3\%D9\%85\%20\%D8\%A7\%D9\%84\%D9\%85\%D8 \%AD\%D8\%A7\%D8\%B3\%D8\%A8\%D8\%A9/cv/\%D8\%B9\%D8\%AB\%D9\%85\%D8\%A7\%D9\%86\%20\%D8\%AD\%D8\%B3\%D9\%8 A\%D9\%86/\%D8\%A7\%D9\%84\%D8\%A8\%D8\%AD\%D8\%AB\%20\%D8\%A7\%D9\%84\%D8\%AB\%D8\%A7\%D9\%86\%D9\%8A.pdf

40. Parasuraman, A, Zeithaml, V. A., \& Berry, L. L. (1985). A conceptual model of service quality and its implications for future research. Journal of Marketing, 49(4), 1-50. https://doi.org/10.1177/002224298504900403

41. Parasuraman, A, Zeithaml, V. A., \& Berry, L. L. (1988). SERVQUAL: A multiple-item scale for measuring consumer perceptions of service quality. Journal of Retailing, 64(1), 12-40. Retrieved from https://pdfs.semanticscholar.org/d26a/2423f00ca372b424a029ae22521299f00ede.pdf

42. Paul, J., Mittal, A., \& Srivastav, G. (2016). Impact of service quality on customer satisfaction in private and public sector banks. International Journal of Bank Market, 34(5), 606-622. https://doi.org/10.1108/IJBM-03-2015-0030

43. Rao, K. S., \& Jagadeesh, G. (2018). Power quality improvement in grid interfaced system using Fuzzy-UPQC controller. International Journal for Modern Trends in Science and Technology, 4(12), 45-50. Retrieved from https://www.ijmtst.com/volume4/issue12/8.IJMTST041217.pdf

44. Rayp, G., \& Van De Sijpe, N. (2007). Measuring and explaining government efficiency in developing countries. The Journal of Development Studies, 43(2), 360-381. https://doi.org/10.1080/00220380601125230

45. Rezvani, M., \& Safahani, N. (2016). The effect of site quality on electronic word of mouth marketing through mediating variable of customer satisfaction (case study: Tiwall culture and art social network online shop). International Business Management, 10(4), 592-598. http://doi.org/10.36478/ibm.2016.592.598

46. Rodriguez, A. S., Campdesuner, R. P., Vidal, G. G., \& Vivar, R. M. (2017). Tools for measuring and improving external customer satisfaction in stores of Santo Domingo, Ecuador. International Journal of Engineering Business Management, 9, 1-12. https://doi.org/10.1177/1847979017723172

47. Salah Eldean, N. S., \& Bartamani, M. S. (2018). Quality of university services at the community service and continuing education center at Sultan Qaboos University: An empirical study using the gap scale between perceptions and expectations. Journal of Educational and Psychological Studies, 12(1), 16-39. https://doi.org/10.24200/jeps.vol12iss1pp16-39

48. Saudi Vision 2030. (2018). The program for achieving financial balance. Retrieved from http://vision2030.gov.sa/ar/bb2020

49. Saudi Vision 2030. (n.d.). Retrieved from Saudi Vision website: http://vision2030.gov.sa/

50. Silva, D. S., de Moraes, G. H. M., Makiya, I. K., \& Cesar, F. I. G. (2017). Measurement of perceived service quality in higher education institutions: A Review of HEdPERF scale use. Quality Assurance in Education, 25(4), 415-439. https://doi.org/10.1108/QAE-10-2016-0058

51. Suleiman, M. I. (2013). The level of quality of university services as perceived by students of Al-Aqsa University in Gaza according to the service quality scale (SERVPERF). Al-Aqsa Journal: Humanities Series, 17. Retrieved from https://www.alaqsa.edu.ps/site_resources/aqsa_magazine/files/744.pdf

52. Sutherland, D., \& Price, R. (2007). Linkage between performance and institutions in the primary and secondary education sector (OECD Economics Department Working Paper No. 558). https://doi.org/10.1787/170826717775

53. Vanpariya, B., \& Ganguly, P. (2010). SERVQUAL versus SERVPERF: An assessment from Indian banking sector. QUEST Journal of Management and Research, 1(1). https://doi.org/10.2139/ssrn.1783471

54. Waldmann, E., \& Ratnatunga, J. (2011). A marketing approach to service quality in accounting: A case study. International Business \& Economics Research Journal, 2(5). https://doi.org/10.19030/iber.v2i5.3795

55. Waldmann, E., \& Ratnatunga, J. (2015). A marketing approach to service quality in accounting: A case study. International Business \& Economics Research Journal, 2(5), 29-43. https://doi.org/10.19030/iber.v2i5.3795

56. Wang, Y., Lo, H.-P., \& Hui, Y.V. (2003). The antecedents of service quality and product quality and their influences on bank reputation: evidence from the banking industry in China. Managing Service Quality: An International Journal, 13(1), 72-83. https://doi.org/10.1108/09604520310456726

57. Wilson, P. W. (2005). Efficiency in education production among PISA countries, with emphasis on transitioning economies.

58. Zeithaml, V. A., Parasuraman, A., \& Berry, L. L. (1985). Problems and strategies in services marketing. Journal of Marketing, 49(2), 33-46. https://doi.org/10.2307/1251563 